\title{
BEHAVIOR OF CONCRETE STRENGTHENED WITH CARBON FIBER REINFORCED POLYMER LAMINATE AT HIGH TEMPERATURE
}

\author{
AZAD A. MOHAMMED * and ABDULJALIL S. AHMED** \\ Department of Civil Engineering, College of Engineering, University of Duhok \\ * E-Mail : azadkadr@yahoo.com \\ ** E-Mail: Aduljalil @yahoo.com
}

\begin{abstract}
In this paper the effect of high temperature on plain concrete strengthened with Carbon Fiber Reinforced Polymer ( CFRP) sheets and behavior of concrete strengthened after heating were studied for flexure and compression properties. For this purpose a total of 44 prismatic specimens of $100 \times 100 \times 350 \mathrm{~mm}$ dimensions were tested. Results indicate that due to high temperature there is a continuous reduction in flexural strength of concrete strengthened with CFRP sheet . Deflection corresponding to flexural strength also reduced for exposure temperature higher than $350^{\circ} \mathrm{C}$. The effect of finishing CFRP layers with cement mortar for controlling the reduction of flexural and compressive strengths due to high temperature was found to be not important. According to the obtained results, plain concrete damage by high temperature can be repaired using CFRP sheets for compressive strength of about $74 \%$ of that of plain concrete, and flexural strength of about $69 \%$ of that of strengthened concrete before heating .
\end{abstract}

KEYWARDS:Bond,CFRP, Compression, Flexure ,Heating, High Temperature, Strengthening, Wrapping

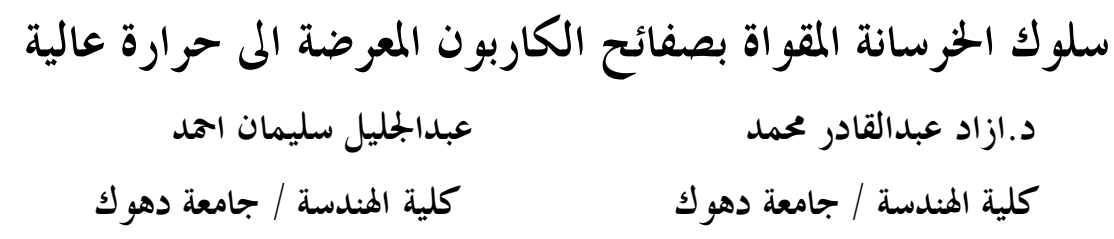

الحلاصة

في البحث الحالي تم دراسة تأثير الحرارة العالية على خواص الانخناء والانضغاط للخر سانة المقواة بصفائح الكاربون ودراسة تأثير التقوية على الحرسانة

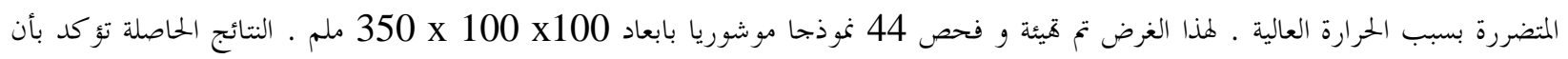

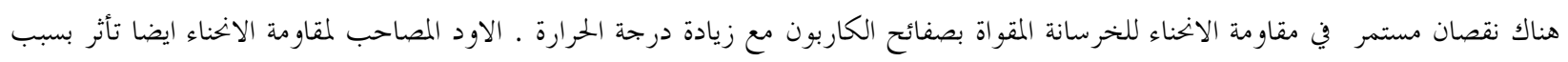

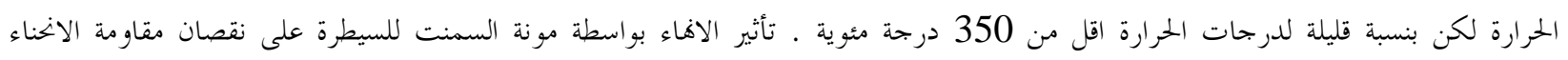

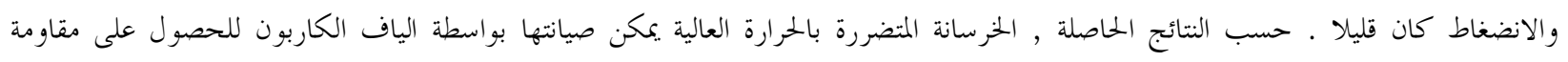

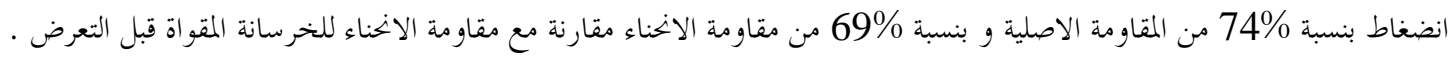




\section{1- INTRODUCTION}

Rehabilitating of deficient structural members and old infrastructures damaged as a result of cracking nowadays can be done successfully. Behavior of strengthened concrete members using different materials are well understood through experimental studies, and design proposals was introduced by researchers. Due to developments occurred in the aspect of materials technology, many types of advanced materials like polymers were developed for using as strengthening sheets or fabrics bonded with epoxies to the concrete surface. Polymer laminates are known by their high tensile strength to weight ratio. The structural performance of concrete bonded with fiber reinforced polymers using epoxy is accepted by engineers but the durability of the strengthened concrete needs to be assessed carefully. One of the most pressing problems related to using fiber reinforced polymer FRP is the bond failure lead to premature sheet separation. For this purpose a number of studies were carried out to understand the durability of bonded fiber reinforced polymers to concrete subjected to different environmental conditions.

The effect of freeze - thaw cycling on the bond behavior between carbon fiber reinforced polymer CFRP and concrete was studied by Green et al ${ }^{[1]}$. Their experimental results indicated that the bond between CFRP strips and concrete is not significantly damaged up to 300 freeze thaw cycles. Tests indicated that the load carrying capacity of beams strengthened with CFRP plates is reduced after long term exposure to $100 \%$ humidity, dry heat, freezing and thawing, and thermal expansion environmental conditions ${ }^{[2]}$.

Basically, both the fiber reinforced plastics and epoxies are an organic materials and their performance is good and usable until their combustion at about $300{ }^{\circ} \mathrm{C}$ as pointed out by Gaylord ${ }^{[3]}$. If the FRP sheets are provided to concrete for strengthening structural members inside buildings and such buildings subjected to high temperature due to fire, the performance of strengthened concrete be in question .

Although the resistance of concrete to high temperature is better than that of steel, it is experimentally evident that many important properties of concrete like compressive strength, tensile strength and elastic modulus are deteriorated due to high temperature ${ }^{[4]}$. At about $800{ }^{\circ} \mathrm{C}$ the mentioned mechanical properties are rigorously damaged and the concrete not be remain usable .

In this paper the relation between concrete subjected to high temperature and strengthening with CFRP are presented through experimental tests. First, the effect of high temperature on flexural strength of concrete strengthened with CFRP is presented. Later the behavior concrete damaged by high temperature and then strengthened with CFRP is studied through testing prismatic specimens in flexure and compression.

\section{2- EXPERIMENTAL}

The properties of concrete materials and fiber reinforced polymer used in the present study is shown in Table ( 1 ). Instead of standard prisms of $100 \times 100$ x $400 \mathrm{~mm}$ dimensions a $100 \times 100$ x $350 \mathrm{~mm}$ prism specimens were prepared for testing. Such specimens of smaller length were used due to the limitations of the furnace dimensions used for heating concrete specimens. All specimens were cast from one mix batch and compacted by compacting standard rod. After casting, all specimens were put inside water tank and cured for 28 days. Concrete Specimens were left in open air to dry for another 28 days before strengthening or heating . 
Details of prismatic concrete specimens are summarized in Table ( 2 ). Two specimens were prepared for testing for variables shown in the table and accordingly the total number of 44 specimens were tested. After drying, the surface of concrete specimen to be wrapped with CFRP was well cleaned and covered by the epoxy mixture ( 1 part resin and 4 parts hardener ) of Sikadur-330 type, and well leveled to obtained a thickness of about $1 \mathrm{~mm}$. Later a CFRP layer was put on the epoxy surface and covered with hard nylon sheet and pressed so as to saturate the layer with the epoxy mixture . For providing other layers of CFRP the process was repeated . For those specimens having surfaces to be finished, additional layer of epoxy was provided and a medium size sand then sprayed on it and left for 48 hours. Later a cement mortar of 1:2 ( cement : sand ) proportion with water/cement ratio of 0.5 was prepared. The surface of specimen then covered with cement mortar and smoothly finished. After 24 hours the specimen covered with wet cloth and left for 7 days.

Table ( 1 ) Properties of Concrete Materials and CFRP

\begin{tabular}{|c|c|c|c|c|}
\hline Material & Туре & Source & $\begin{array}{l}\text { Specific } \\
\text { Gravity }\end{array}$ & Grading \\
\hline Cement & $\begin{array}{l}\text { Ordinary Portland } \\
\text { Cement ( Type I ) }\end{array}$ & Kurtlan/Turkey & 3.14 & - \\
\hline $\begin{array}{c}\text { Fine } \\
\text { Aggregate }\end{array}$ & $\begin{array}{l}\text { Medium size river } \\
\text { sand }\end{array}$ & $\begin{array}{c}\text { Fishkhabor } \\
\text { Quarry }\end{array}$ & 2.71 & $\begin{array}{l}\text { Passing by } 100 \% \text { on } \\
4.75 \mathrm{~mm} \text { sieve and of } \\
2.45 \text { fineness modulus }\end{array}$ \\
\hline $\begin{array}{c}\text { Course } \\
\text { Aggregate }\end{array}$ & $\begin{array}{l}\text { Well graded rounded } \\
\text { shape river gravel }\end{array}$ & $=$ & 2.76 & $\begin{array}{c}\text { Passing by } 100 \% \text { on } 10 \\
\text { mm sieve }\end{array}$ \\
\hline
\end{tabular}

\begin{tabular}{|c|c|c|c|c|c|}
\hline Concrete & $\begin{array}{c}\text { Mix } \\
\text { Proportion }\end{array}$ & $\begin{array}{c}\text { w/c } \\
\text { Ratio }\end{array}$ & Cement $\left(\mathrm{kg} / \mathrm{m}^{3}\right)$ & $\begin{array}{c}\text { Fine Agg. } \\
\left(\mathrm{kg} / \mathrm{m}^{3}\right)\end{array}$ & $\begin{array}{c}\text { Coarse Agg. } \\
\left(\mathrm{kg} / \mathrm{m}^{3}\right\}\end{array}$ \\
\hline Properties & $1: 1.5: 3$ & 0.5 & 408 & 812 & 1224 \\
\hline
\end{tabular}

\begin{tabular}{|l|c|c|c|c|c|c|}
\hline CFRP Type * & $\begin{array}{c}\text { Areal } \\
\text { Weight }\end{array}$ & $\begin{array}{c}\text { Fiber } \\
\text { Density }\end{array}$ & $\begin{array}{c}\text { Fabric } \\
\text { design } \\
\text { Thickness }\end{array}$ & $\begin{array}{c}\text { Tensile } \\
\text { Strength } \\
(\mathrm{MPa})\end{array}$ & $\begin{array}{c}\text { Elastic } \\
\text { Modulus } \\
\text { ( MPa })\end{array}$ & $\begin{array}{l}\text { Strain at } \\
\text { Break of } \\
\text { Fibers }\end{array}$ \\
\hline $\begin{array}{l}\text { SikaWrap-230C } \\
\text { (Unidirectional } \\
\text { Fibers ) }\end{array}$ & $\begin{array}{c}220 \\
\mathrm{~g} / \mathrm{m}^{2}\end{array}$ & $1.7 \mathrm{~g} / \mathrm{cm}^{3}$ & $0.12 \mathrm{~mm}$ & 4100 & 231000 & $1.7 \%$ \\
\hline
\end{tabular}

* Data provided by the manufacturer 
Table ( 2 ) Detail of Specimens Properties

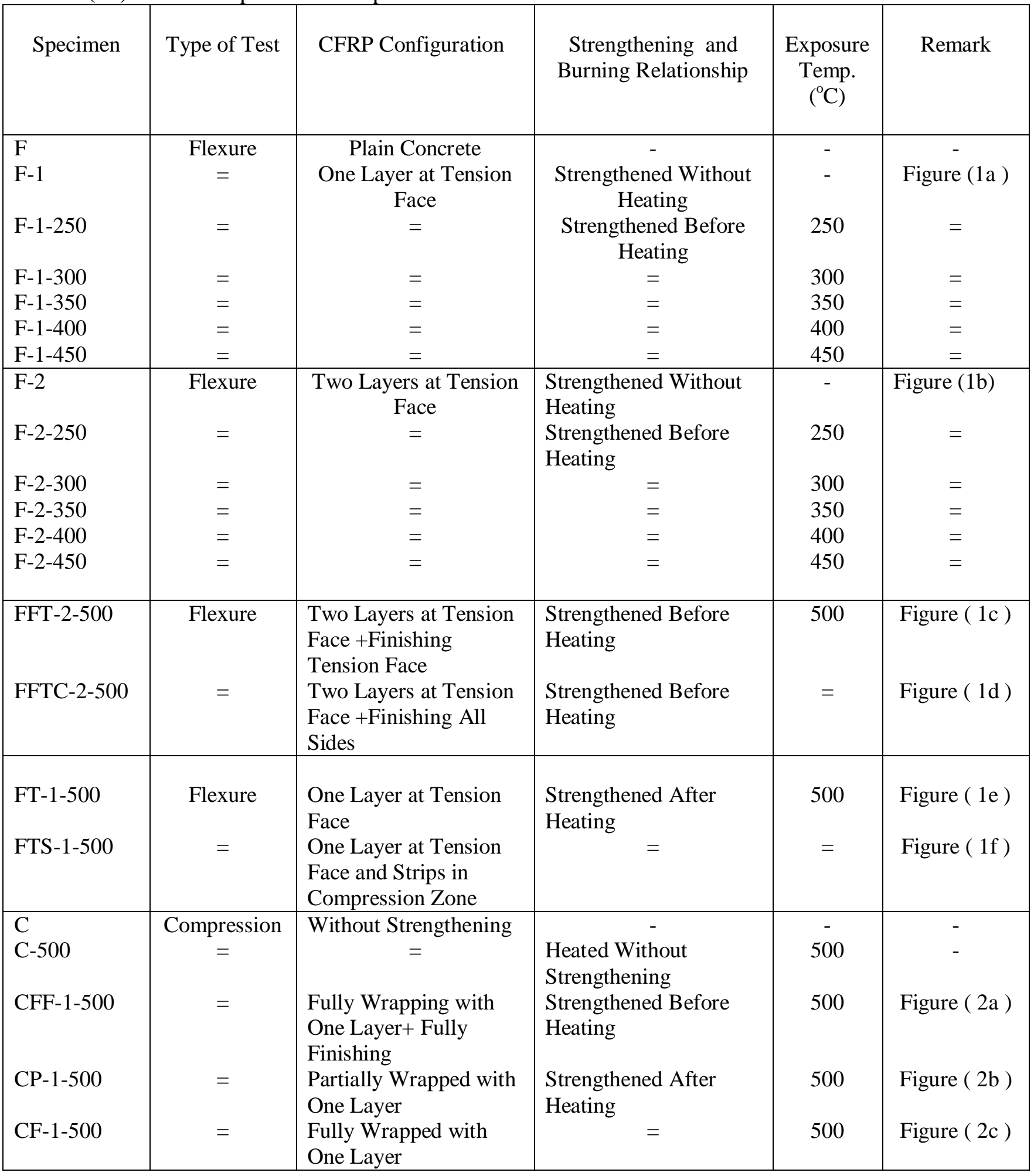




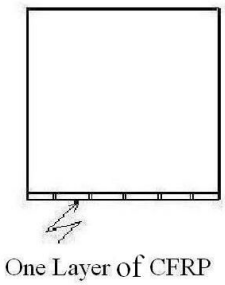

(a)

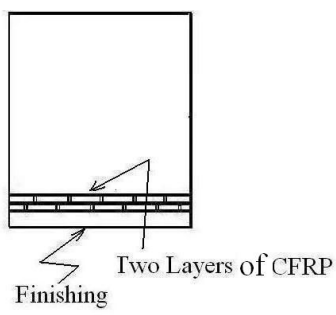

(c)

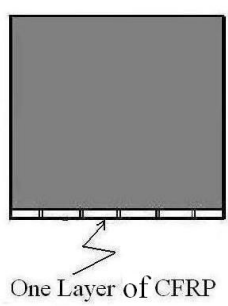

(e )

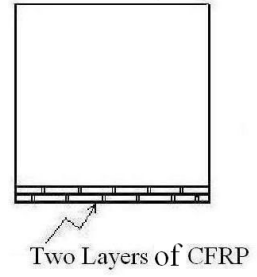

(b)

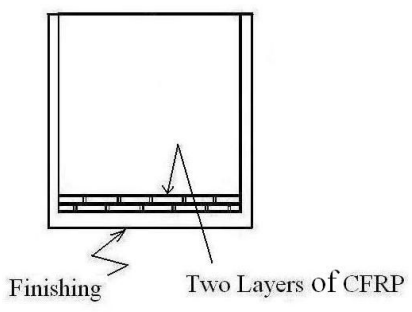

(d)

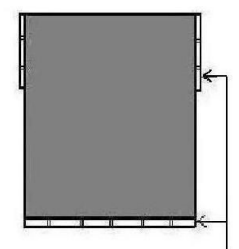

One Layer at Tension Face and Strips in Compression Zones

(f)

Figure ( 1 ) Detail of Cross Section of Flexural Specimens

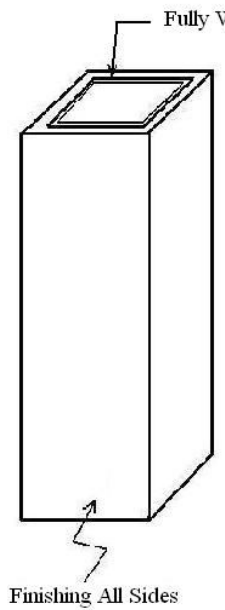

(a)

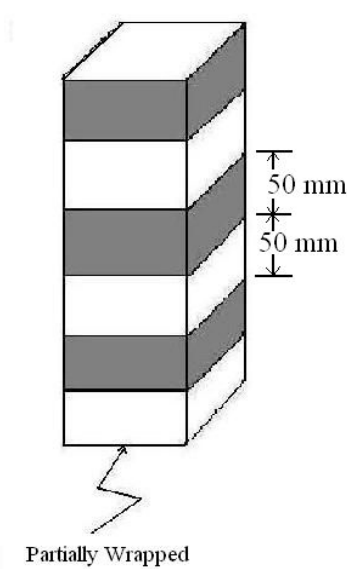

(b)

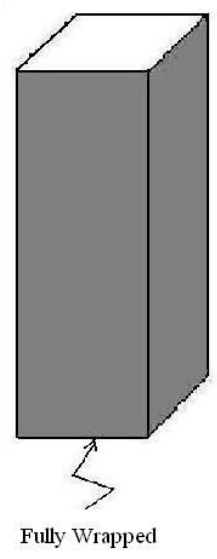

(c)

Figure ( 2 ) View of Strengthened Compression Specimens 
After strengthening and finishing, all specimens were dried before subjecting to high temperature at $105^{\circ} \mathrm{C}$ temperature for $24 \mathrm{hrs}$. Those specimens exposed to high temperature were put horizontally inside the heating furnace and subjected to various temperatures according to the detail shown in Table ( 2 ). The rate of temperature increase was $380{ }^{\circ} \mathrm{C} / \mathrm{hr}$ and after reaching the desired temperature heating was continued for $1 \mathrm{hr}$. After burning, all specimens were left in the laboratory and tested after $24 \mathrm{hrs}$ for flexural strength or compressive strength or strengthened with CFRP layer and then tested, all according to the configuration shown in Table(2 ). All flexural specimens were tested to ultimate load by the mean of two central point loads over a clear span equal to $270 \mathrm{~mm}$ and shear span equal to $90 \mathrm{~mm}$ and the results of flexural strength and the corresponding deflection were taken from the output of the device. The rate of load increment used for testing flexural and compression specimens was $5 \mathrm{kN} / \mathrm{min}$. After testing photographs were taken to illustrate the cracking pattern and the appearance due to physical changes take place as a result of high temperature.

\section{3- RESULTS AND DISCUSSION}

Table ( 3 ) shows the results of flexural strength, corresponding central deflection, and compressive strength of concrete specimens for different wrapping configuration. The values shown in the table are the average result obtained from testing two identical specimens. The role of different parameters affecting the strength and deformation of concrete strengthened with CFRP sheets in contact with high temperature in some detail is discussed in the following paragraphs.

\section{3-1 Effect of High Temperature on Flexural Strength}

Flexural strength of plain concrete was $3.77 \mathrm{MPa}$ and found to fail at the central zone of the specimen as a result of a single crack. Oppositely those specimens strengthened with one and two layers of CFRP were failed in shear [ Figure ( 5 ) ]. This occurs due to high flexural capacity as a result of strengthening tension face of the specimen with CFRP. After strengthening, the flexural strength of concrete was increased to $299 \%$ and $443 \%$ due to strengthening with one layer and two layers of CFRP, respectively. Figure ( 3 ) shows the variation of flexural strength of strengthened concrete with one layer and two layers of CFRP with temperature increase . As the flexural strength results are compared with that of control specimens one can found that the flexural strength of concrete is affected with the temperature increase and rigorously damaged when the temperature be higher than $350^{\circ} \mathrm{C}$. The percentage of residual flexural strength is $29 \%$ and $32 \%$ for specimen strengthened with one and two layers, respectively at $400^{\circ} \mathrm{C}$ and $24 \%$ at $450^{\circ} \mathrm{C}$ compared with that of plain concrete. Such percentages are only $8 \%$ and $5 \%$ of the strengthened control specimen. Observing the nature of heated specimens indicates that due to high temperature and after $350^{\circ} \mathrm{C}$ the color of epoxy bonding is changed from grey to black as shown in Figure ( 6 ) and at $450^{\circ} \mathrm{C}$ it changed to white powder deposit [ Figure ( 7 ) ]. Comparing results of specimens strengthened with one layer and two layers of CFRP shown in Figure ( 3 ) indicate that the flexural strength of specimens with two layers is lower than that strengthened with one layer of CFRP at all exposure temperatures. Therefore flexural strength and hence the performance of concrete is reduced more due to high temperature when the amount of CFRP layer is increased. This can be argued from the fact that the epoxy material which is flammable not affected only by high temperature but can act as an enhancement tool for 
burning plain concrete and affecting concrete through flam blows lead to more reduction in flexural strength .

Table ( 3 ) Test Results of Specimens

\begin{tabular}{|c|c|c|c|c|c|c|}
\hline Specimen & $\begin{array}{l}\text { Ultimate } \\
\text { Stress } \\
(\mathrm{MPa})\end{array}$ & $\begin{array}{l}\text { Central } \\
\text { Deflection } \\
(\mathrm{mm})\end{array}$ & $\begin{array}{l}\text { Ratio of } \\
\text { Stress to } \\
\text { Plain } \\
\text { Concrete } \\
\text { Stress,\% }\end{array}$ & $\begin{array}{l}\text { Ratio of } \\
\text { Stress to } \\
\text { Strengthened } \\
\text { Concrete } \\
\text { Stress,\% }\end{array}$ & $\begin{array}{l}\text { Ratio of } \\
\text { Deflection to } \\
\text { Plain Concrete } \\
\text { Deflection ,\% }\end{array}$ & $\begin{array}{l}\text { Ratio of } \\
\text { Deflection to } \\
\text { Strengthened } \\
\text { Concrete } \\
\text { Deflection,\% }\end{array}$ \\
\hline $\begin{array}{l}\text { F } \\
\text { F-1 } \\
\text { F-1-250 } \\
\text { F-1-300 } \\
\text { F-1-350 } \\
\text { F-1-400 } \\
\text { F-1-450 }\end{array}$ & $\begin{array}{c}3.77 \\
11.28 \\
11.41 \\
8.1 \\
7.24 \\
1.10 \\
0.89\end{array}$ & $\begin{array}{c}2.0 \\
3.48 \\
3.6 \\
3.25 \\
2.9 \\
1.21 \\
0.8\end{array}$ & $\begin{array}{l}100 \\
299 \\
303 \\
215 \\
192 \\
29 \\
24\end{array}$ & $\begin{array}{c}33 \\
100 \\
101 \\
72 \\
64 \\
10 \\
8\end{array}$ & $\begin{array}{c}100 \\
174 \\
180 \\
163 \\
145 \\
61 \\
40\end{array}$ & $\begin{array}{c}57 \\
100 \\
103 \\
93 \\
83 \\
35 \\
23\end{array}$ \\
\hline $\begin{array}{l}\text { F-2 } \\
\text { F-2-250 } \\
\text { F-2-300 } \\
\text { F-2-350 } \\
\text { F-2-400 } \\
\text { F-2-450 }\end{array}$ & $\begin{array}{l}16.70 \\
8.62 \\
4.64 \\
3.93 \\
1.22 \\
0.91\end{array}$ & \begin{tabular}{c|}
3.5 \\
3.3 \\
2.8 \\
3.46 \\
1.16 \\
0.81
\end{tabular} & $\begin{array}{l}443 \\
229 \\
123 \\
104 \\
32 \\
24\end{array}$ & $\begin{array}{c}100 \\
52 \\
28 \\
24 \\
7 \\
5\end{array}$ & $\begin{array}{c}175 \\
165 \\
80 \\
173 \\
58 \\
23\end{array}$ & $\begin{array}{c}100 \\
94 \\
80 \\
99 \\
33 \\
23\end{array}$ \\
\hline $\begin{array}{l}\text { FFT-2-500 } \\
\text { FFTC-2-500 }\end{array}$ & $\begin{array}{l}0.38 \\
0.49\end{array}$ & $\begin{array}{l}0.40 \\
0.65\end{array}$ & $\begin{array}{l}10 \\
13\end{array}$ & $\begin{array}{l}2 \\
3\end{array}$ & $\begin{array}{l}20 \\
33\end{array}$ & $\begin{array}{l}11 \\
19\end{array}$ \\
\hline $\begin{array}{l}\text { FT-1-500 } \\
\text { FTS-1-500 }\end{array}$ & $\begin{array}{c}6.78 \\
7.8\end{array}$ & $\begin{array}{l}2.3 \\
4.9\end{array}$ & $\begin{array}{l}180 \\
207\end{array}$ & $\begin{array}{l}60 \\
69\end{array}$ & $\begin{array}{l}115 \\
245\end{array}$ & $\begin{array}{c}66 \\
141\end{array}$ \\
\hline $\begin{array}{l}\mathrm{C} \\
\mathrm{C}-500 \\
\text { CFF-1-500 } \\
\text { CP-1-500 } \\
\text { CF-1-500 }\end{array}$ & $\begin{array}{l}21.46 \\
1.85 \\
2.53 \\
2.07 \\
15.9\end{array}$ & $\begin{array}{l}- \\
- \\
- \\
- \\
-\end{array}$ & $\begin{array}{c}100 \\
8 \\
12 \\
10 \\
74\end{array}$ & $\begin{array}{l}- \\
- \\
- \\
-\end{array}$ & $\begin{array}{l}- \\
- \\
- \\
-\end{array}$ & $\begin{array}{l}- \\
- \\
- \\
-\end{array}$ \\
\hline
\end{tabular}

\section{3-2 Effect of High Temperature on Deflection}

Results of central deflection corresponding to the ultimate load are shown in Table ( 3 ). Ratios of deflection of flexural specimens exposed to high temperature to that of plain concrete and 
strengthened concrete specimens before heating are also shown in the table. Figure ( 4 ) shows the variation of deflection with temperature increase. It is shown that the deflection is reduced slowly for temperatures lower than $350^{\circ} \mathrm{C}$ and there is sudden reduction between $350^{\circ} \mathrm{C}$ and $400^{\circ} \mathrm{C}$. At $400^{\circ} \mathrm{C}$ temperature the ratio is $61 \%$ for one layer CFRP and $58 \%$ for two layers of the plain concrete deflection and only $35 \%$ and $33 \%$ of that of strengthened concrete. At $450{ }^{\circ} \mathrm{C}$ such ratio for most of the specimens is $23 \%$. As compared to the ratio of residual flexural strength the percentage reduction in deflection is lower especially for temperature lower that $350^{\circ} \mathrm{C}$. As the results of Table ( 3 ) are compared one can observe that the role of the addition of other layers to strengthened concrete is not important on the reduction of deflection with temperature. In general the effect of high temperature on the deflection corresponding to flexural strength is lower that the flexural strength itself .

\section{3-3 Effect of Finishing on Flexural Strength and Deflection}

To study the effect of protecting CFRP layer with cement mortar finishing, two specimens strengthened with CFRP layer and covered with cement mortar at the tension face and at three sides ( specimens FFT-2-500 and FFTC-2-500 ) are tested for ultimate load and deflection. Results of these specimens are shown in Table ( 3 ). As the results compared with those specimens without protection or finishing, the role of finishing can be considered negligible. The reason of this observation can be argued from the fact that due to high temperature both CFRP layer and epoxy are damaged and their physical properties are changed and left the weak space between the mortar layer and concrete specimen to be easily separated from concrete even at small deformation. Before testing all finishing layers were fall down due to debonding. Figure ( 7 ) shows the view of specimen with finishing after testing.

\section{3-4 Effect of Strengthening on Flexural Strength of Concrete Exposed to High Temperature}

In order to study the effect of strengthening concrete subjected to high temperature with CFRP four specimens were tested, two in flexure and others in compression. These specimens were previously subjected to $500^{\circ} \mathrm{C}$ temperature, cooled down to room temperature and then strengthened with one layer of CFRP. Percentage of flexural strength for those specimens strengthened at tension face is $180 \%$ and $60 \%$ compared with that of control plain and strengthened concrete specimens, respectively. Such percentages are increased to $207 \%$ and $69 \%$ when strips of CFRP are provided to compression zone of flexural specimens in addition to that at tension face. The difference of $27 \%$ and $9 \%$ were occurred due to the increase of shear strength of concrete as a result of strengthening sides of specimen in compression zone. According to the obtained results any plain concrete damaged by high temperature can be repaired successfully with layers of CFRP. Results of Table( 3 ) also indicate that the percentage of deflection of concrete specimen corresponding to ultimate load is $115 \%$ of that of plain concrete and $66 \%$ of that of strengthened concrete when the specimen bonded with one layer of CFRP at tension face. For those specimens strengthened with strips in compression zone the ratio of deflection is $245 \%$ and $141 \%$. The later defection is higher than $100 \%$ because comparison was made with that of specimen strengthened with CFRP layer at tension face only ( specimens $\mathrm{F}$ and F-1 ). The later two deflections is higher than the previous value due to ductility increase as a result of strengthening compression zone with CFRP strip. 


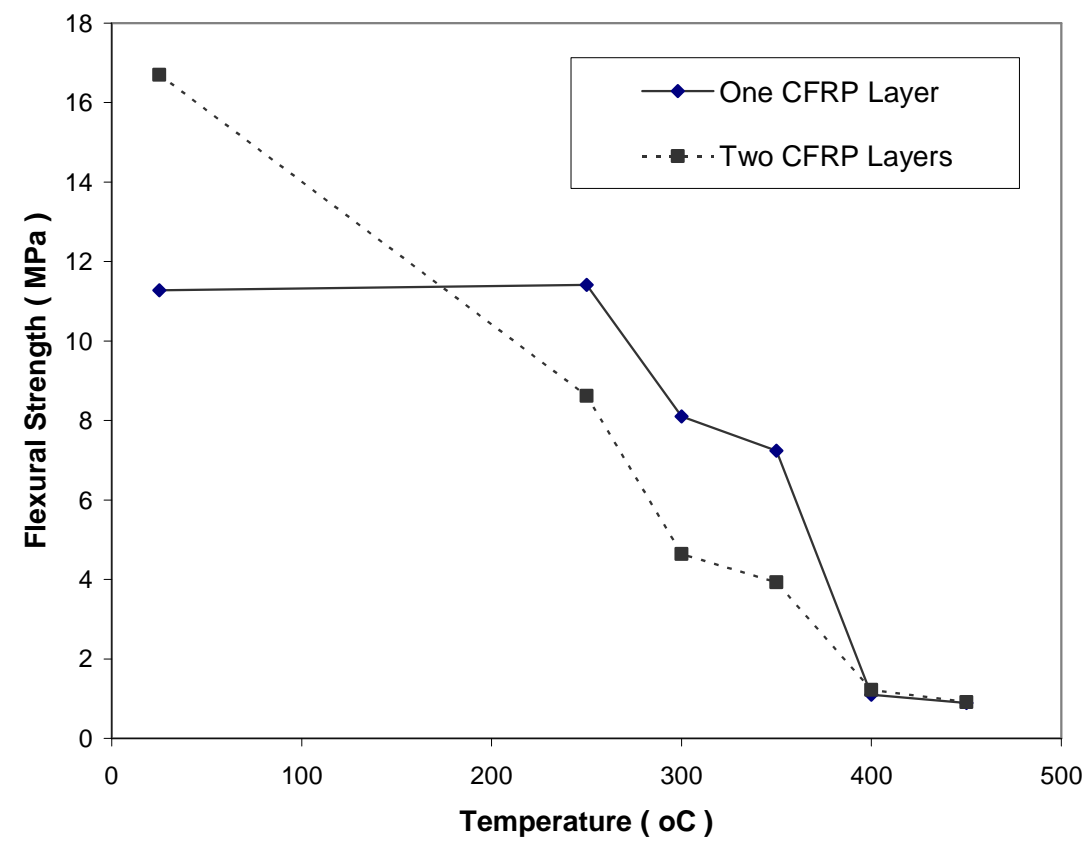

Fig.( 3 ) Variation of Flexural Strength With Temperature Rise

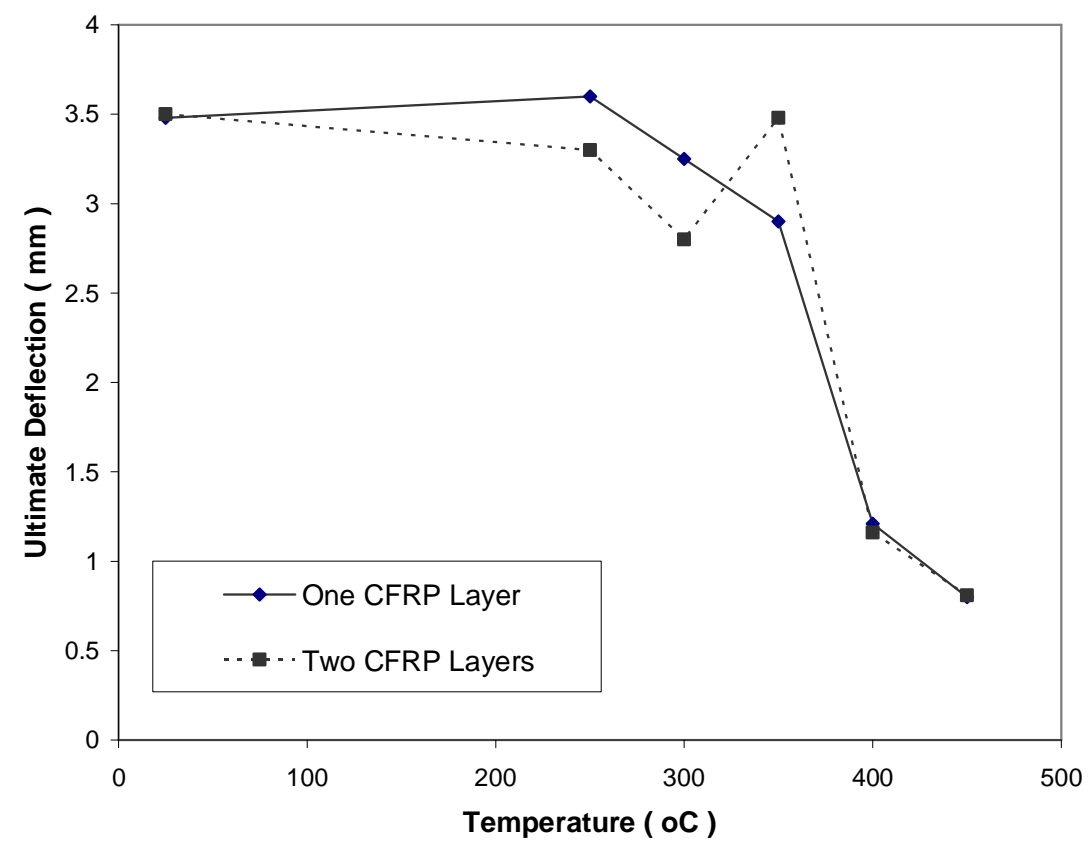

Fig.( 4 ) Variation of Central Deflection With Temperature Rise 


$\begin{array}{lllll}\text { Al-Rafidain Engineering } & \text { Vol.18 } & \text { No.5 } & \text { October } & 2010\end{array}$

\section{3-5 Compressive Strength of Wrapped Concrete Exposed to High Temperature}

According to the results of Table( 3 ) the performance of strengthened concrete in compression subjected to high temperature is not better than that in flexure. Percentage of compressive strength of specimen subjected to $500^{\circ} \mathrm{C}$ is $12 \%$ and $8 \%$ of that of control plain concrete, for heated plain and strengthened concrete specimens, respectively. This result indicates that due to high temperature the confinement effect which is responsible to increase the compressive strength diminishes as a result of reducing the bond between CFRP and concrete. Therefore the compressive strength is similar to that of plain concrete subjected to high temperature. The difference is only $4 \%$ remains for the effect of strengthening which is too small and can be considered not important. It should noted that the strengthened specimen has also surfaces protected against high temperature with cement mortar finishing but was found to affect no on controlling damaging the strengthened concrete by high temperature. After heating and before testing a few number of cracks was seen along the specimen [ Figure ( 11 )] resulted from thermal expansions due to the low tensile strength of thin section finishing mortar. After testing, stresses will produce axial and lateral deformations and due to weak bond of epoxy material as a result of high temperature the finishing layer will easily separate from the specimen and disrupts. Figure ( 12 ) shows the view of such specimen after testing .

\section{3-6 Strength of Concrete Subjected to High Temperature then Wrapped}

Two specimens were tested to study the effect of wrapping on concrete subjected to $500^{\circ} \mathrm{C}$ temperature. One specimen was partially wrapped ( after heating with $500^{\circ} \mathrm{C}$ ) with CFRP strips $50 \mathrm{~mm}$ in width and of $50 \mathrm{~mm}$ spacing between them and the other specimen was fully wrapped. Table( 3 ) contains results of such specimens after testing for compressive strength. For partially wrapped specimen the ratio of compressive strength is only $10 \%$ increase of that of plain concrete while for the fully wrapped concrete the ratio is $74 \%$. In that specimen partially wrapped with CFRP when the specimen is stressed under loading, there is already locations available without wrapping and therefore remain without confinement and considered weak zones that concrete crushes in a lower stress level compared with strengthened zones. As a result of such weak zones other strengthened zones remains useless. Therefore for obtaining better results of strengthening, the concrete must be fully wrapped. In the case of full confinement, the concrete acts in its biaxial stress state and can carry higher load capacity. The ratio of compressive strength for the fully wrapped concrete is $74 \%$ and as compared with that of flexural strength which is $180 \%$ and 207\% ( specimens FT-1-500 and FTS-1-599) the performance of heated concrete in compression is lower than that in flexure when strengthened with CFRP sheets as a repairing material. 


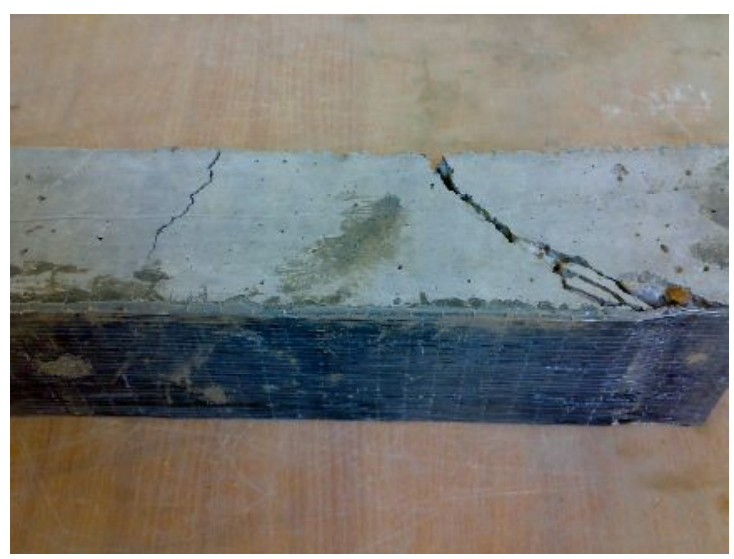

Figure ( 5 ) Specimen F-2

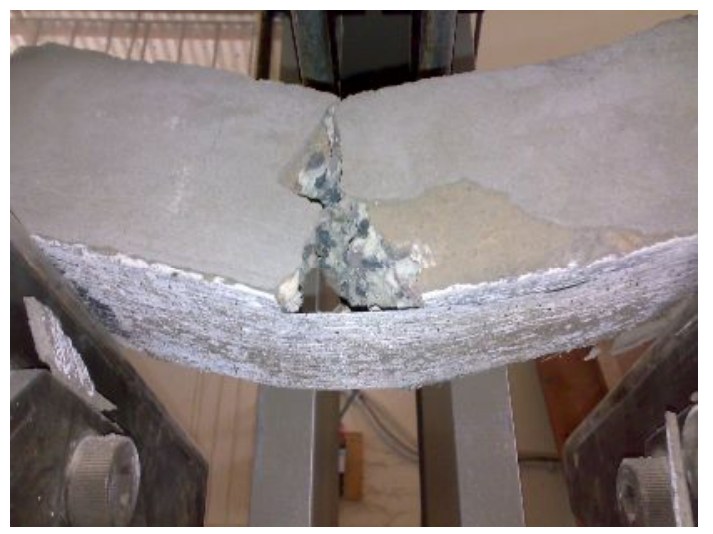

Figure( 7 ) Specimen FFT-2-500

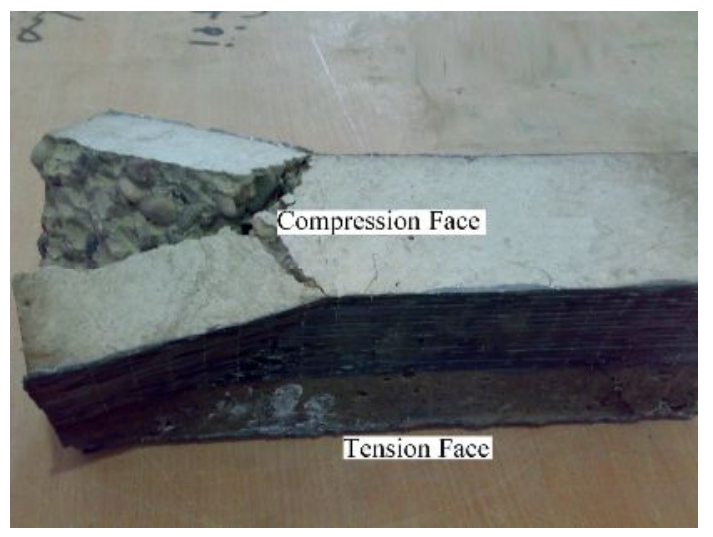

Figure( 9 ) Specimen FTS-1-500

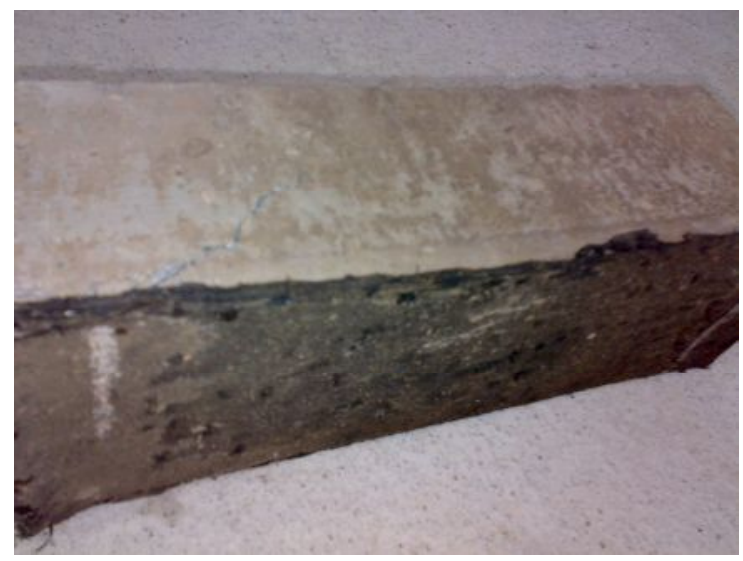

Figure( 6 ) Specimen F-2-300

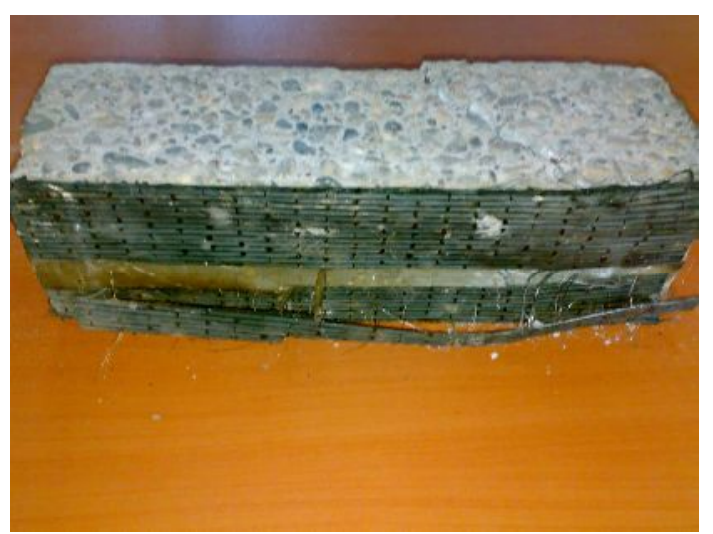

Figure( 8 ) Specimen F-1-250

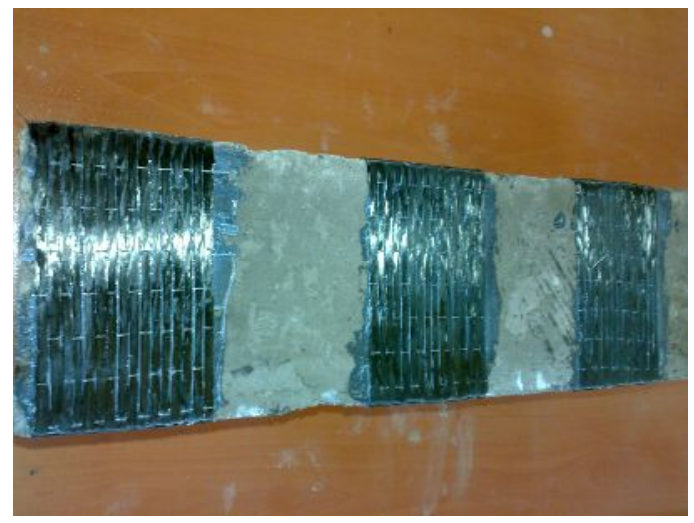

Figure( 10 ) Specimen CP-1-500 


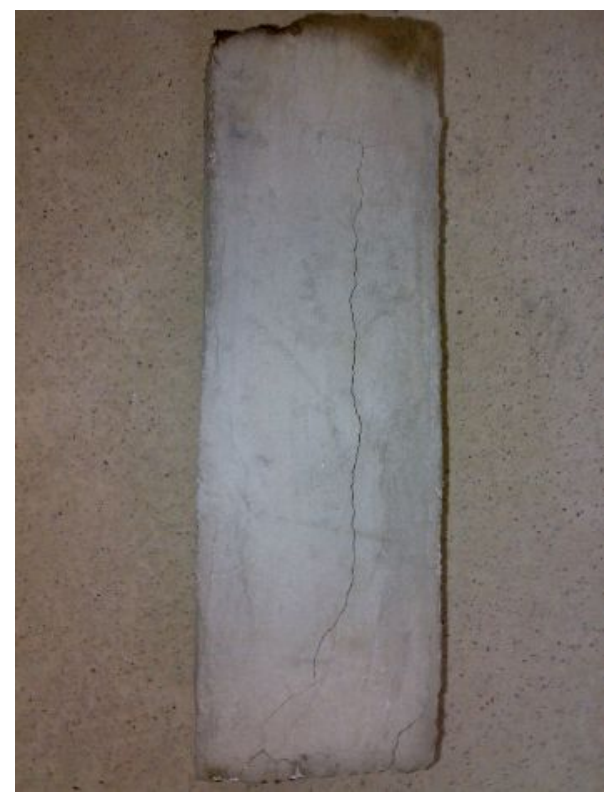

Figure( 11 ) Specimen CF-1-500 (Before Testing)

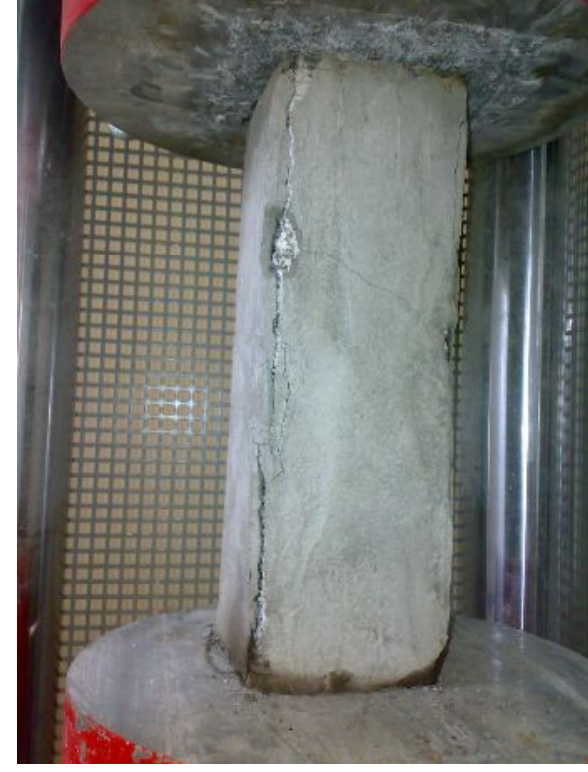

Figure( 12 ) Specimen CF-1-500 (After Testing)

\section{4- CONCLUSSIONS}

From the experimental study presented in this research the following conclusion can be drawn :

1- There is a continuous reduction in flexural strength of plain concrete strengthened with CFRP sheets with temperature rise. The ratio of flexural strength to that of plain concrete is reduced to $24 \%$ and to that of strengthened concrete reduced to $5 \%$ at $450^{\circ} \mathrm{C}$.

2- The deflection corresponding to flexural strength was not considerably reduced for temperature exposure lower than $350^{\circ} \mathrm{C}$ but suddenly reduced to about $23 \%$ at $450^{\circ} \mathrm{C}$.

3- The role of additional layers of CFRP bonded to the strengthened layer was found to be not important for controlling the reduction in flexural strength and the corresponding deflection.

4- The role of cement mortar finishing provided to CFRP layer for controlling damages due to high temperature was found to be not important.

5- Plain concrete damaged by high temperature can be repaired using CFRP laminate for flexural strength of about $69 \%$ of that of strengthened concrete and about two times of that of plain concrete.

6- Plain concrete damaged by high temperature can be repaired for compressive strength of about $74 \%$ of that of plain concrete provided that the concrete fully wrapped with CFRP sheets. 


\section{REFERENCES}

1- Green , M.F. , Bisby , L.A., Beaudoin , Y. and Labossieve , P. ," Effect of Freeze-Thaw Cycles on the Bond Durability Between Fiber Reinforced Polymer Plate Reinforcement and Concrete", Canadian Journal of Civil Engineering , Vol.27 ,2000, pp.949-959

2- Grace , N.F. , and Singh , S.B. ," Durability Evaluation of Carbon Fiber Reinforced Polymer Strengthened Concrete Beams : Experimental Study and Design ", ACI Structural Journal, Vol.102, No. 1 , 2005 , pp. 40-48

3- Gaylord , E.H. , Gaylord , C.N. , and Stallmeyer , J. E. ," Structural Engineering Handbook ( $4^{\text {th }}$ Edition ). New York : McGraw - Hill , 1997

4- Neville, A.M. ," Properties of Concrete ( $3^{\text {rd }}$ Edition $)$, UK, 1995 